\title{
The Calculation of Product Combination by Using Linear Programing Simplex Method to Profit Maximize at Roti Sahabat Palembang City
}

\author{
Afrizawati Afrizawati ${ }^{1, *}$ Elisa Elisa ${ }^{1}$, M.Riska Maulana Effendi ${ }^{1}$, Paisal Paisal ${ }^{1,}$
}

Nurya Mellinda ${ }^{1}$

${ }^{I}$ State Polytechnic of Sriwijaya
${ }^{*}$ Corresponding author. Email: afrizawati@polsri.ac.

\begin{abstract}
This reseach discussed about the calculation of product combinatioans by using a linear program simplex method to calculated product combinations maximize profits at Roti Sahabat. The datas for the preparation of this reseach was obtained through interviews with business owners to obtain primary data. Product of Roti Sahabat was located in Palembang City such as Pia bread and sponge bread which price of them idr 900 per pack. Roti Sahabat produces 24.000 pia bread and 28.800 sponge bread in every month. The production volume is only calculted based on customer demand. To calculated product combination reseach used the maximum simplex method of linear programming and obtained 0 combinations of pia bread and 62.207 for sponge roti, with profit of 30.109.768.2 for a month. The income earned before and after by using the maximum method was very different. Therefore the reseach has suggestion that roti sahabat must used product combination first to calculated the profit.
\end{abstract}

\section{Keywords : Product Combination, Program Linear, Maximum Simplex Method}

\section{INTRODUCTION}

Development is growing and more people was decided to become entrepreneurs, either by buying a brand or creating as a personal business in form service or goods. In addition, the opportunity to market products through socual media is now wider, making it easier for public to present their business. Many of UMKM in the communities will make indonesian peoples futher advance rather than alwyas relying on work prepared by goverment. Job opportunities that goverment prepared was shrinking day by day. In this case the people can realize te revival of goverment that goal of indonesian national income is through from entrepreneur.

Currently, many of business was moving in their production basic needs. One of them is in field food or cooking production. Because of production is a small form of business so the risk will have small too and its often easy to expand quickly. Basicly food needs were basic needs for everyone. Production is all activities that created to increase in use of goods or services. In economics the elements of production activities are needed of land labor and skills. Production of activities are the pioneers of the company, because the company can carry out all the activities within company trough production product such as promotional activities, distribution of goods or services and making processes[1]. Through these productive activities company which can make customer sastify needs and fulfill market needs.

Roti sahabat Palembang city is a bakery company that was founded in 2001 and located on jalan Tunas Harapan Lorong Mawar RT. 10 RW.06 Sako district Sukamaju Palembang. Based on the result interview with the owner Roti Sahabat, they didnot accounted how many production product by detail to achieve level of profit, nor they calculated productions cost in detail. Therefore the management of a company must be able to decide how to used resources to obtain the highest production volume, so if the product was sold, it will definetely get a lot of sale and get profit.

In the linear model program, there are has two fuctions, namely the objective fuction and the contsraint fuction. The objective fuction is a fuction that describes the goals or objective in linear problem programming which related to resources optimization management 
[2]. The contsraint fuction is the resource with the higher benefit or lower cost. When modelling had a purposed to archieved in a linear mathematicaly fuction.
Based on the datas from this reseach was obtained in last two years such as the output (volume), product saleand price of Roti Sahabat palembang.

Table 1. Estimated Average Production Cost, Production Volume, Total Sale Revenue and Profit Pia Bread Each Years 2018 till 2020

\begin{tabular}{|c|c|c|c|c|}
\hline Year & Production Cost & $\begin{array}{c}\text { Production } \\
\text { Volume }\end{array}$ & Sales Volume & Total Sales Revenue \\
\hline 2018 & $\mathrm{Rp} 158.112 .000$ & 345.600 & 344.500 & $\mathrm{Rp} \mathrm{311.040.000.}$ \\
\hline 2019 & $\mathrm{Rp} 131.328 .000$ & 259.200 & 258.000 & $\mathrm{Rp} \mathrm{233.280.000.}$ \\
\hline 2020 & $\mathrm{Rp} 103.968 .000$ & 216.000 & 214.300 & $\mathrm{Rp} \mathrm{194.400.000.}$ \\
\hline
\end{tabular}

Source: Roti Sahabat, 2021

Table 1. showed estimated cost for making pia bread at least 3 years anyway, and there is also a table estimated cost of sponge (bolu) cake for last 3 years also.

Table 2. Estimated Average Production Cost, Production Volume, Total Sale Revenue and Profit Sponge (Bolu) cake Each Years 2018 till 2020

\begin{tabular}{|c|c|c|c|c|}
\hline Year & Production Cost & $\begin{array}{c}\text { Production } \\
\text { Volume }\end{array}$ & Sales Volume & Total Sales Revenue \\
\hline 2018 & $\mathrm{Rp} 158.112 .000$ & 345.600 & 344.500 & $\operatorname{Rp~311.040.000.}$ \\
\hline 2019 & $\mathrm{Rp} 131.328 .000$ & 259.200 & 258.000 & $\operatorname{Rp} 233.280 .000$. \\
\hline 2020 & $\mathrm{Rp} 103.968 .000$ & 216.000 & 214.300 & $\operatorname{Rp~} 194.400 .000$. \\
\hline
\end{tabular}

Sources: Roti Sahabat, 2021

As can be seen from the table above, we known the production and sale of profit from Roti Sahabat must achieved, how to avoid losses and how to plan for the future profitability of the company, so it will prevent the company from experience a decline in profitability as it is today. According the combination of linear production program to increase the profit or to find out decrease in profits therefore doesnt make the store lossesso the tittle of this reseach is Calculation of Combination Product By Using Linear Programing Simplex Method to Profit Maximize At Roti Sahabat Palembang.

\section{LITERATURE REVIEW}

\subsection{Producet Definition}

Product is the result of productiion activities carried out by producers to satify needs and desires of consumers. Products sold by consumers must be good qualit, affordable, easy to obtain and involved in promotional activities, so that consumers can interest in buying the company's product. Products can be sold in large quantities will provide income and make profit for the company. [3] states that aproduct is anything that can be offered to a market for attention, acquisition, use and consumption that can satify a want or need. Products are more than just things that can be measured. Products include physical goods, services, people, organizations, ideas or combination of these.

\subsection{Production Combination}

Product can be produced in various ways and technologie, although there are many production processes, they can be broadly devided into two categories, namely: companies are organization whose activities are producing. Production activities are activities that change the form of raw materials into final product (good and services)[8]. Companies need raw materials, machine tools and labor. The company cannot be separated from its production and operation functions because one of the company cannot be separated from its production and operation fuctions. Because one ofthe company's tasks is to produce goods and services. The company by raw and auxiliary materials and processes them manually into final products.

According, [4] combination of product is a comparisson of the amount between one product and another that must be produced within a certain period in order to obtain optimal income. Product combination problems occur in companies that produce more than one product. The problem is how to determine the quantity of each product and what type of product will be produced so that the company can be take advantage of existing resources and get as much profit as possible. Therefore, it can be concluded that product mix is a way of determining amount of various products produced by using production factors such as machinery, labor and raw materials. The company must be able to determine 
the number and type of product to be produced firmly in order to obtain the best results. The number of types of products to be produced must be determined by calculating the cost and value of the product itself based on the ability of business resources to determine the best product combination for the highest profit.

\subsection{Linear Programming}

According to sweeney and colleagues in his book "introducton and Management Science" linear programming is a mathematical technique develop to assist a manager for making secisions. As [5] linear programming (LP) is used tp solve problems that require solving in the proccess or maximally or minimally by using mathematic techniques in the form of linear inequalities. Based on the liniear programming theory above, it can be concluded that linear programming is a technology that solves problems in a maximum or minimum procces to help companies. Liniear programming the mathematical modality of product combination problems can be described in the form of a linear curve (straight line). The implication of the linear nature requires proposionality and additivity.

\subsection{Simplex Method}

The simplex method is the process of repeating system procedures (literacy) until desired results is achieved. Therefore, this method replaces difficukt questionwith a series of simple questions. According to [6] the simplex method is one of the solutions of linear programming which teh process of finding a solition is using the literacy path, namely determining feasible point of the goal to be achieved with the help of table untill the optimal solution is obtained.

Table 3. Initial Simplex Table

\begin{tabular}{|l|l|l|l|l|l|l|}
\hline asis & $\mathbf{X}_{\mathbf{1}}$ & $\mathbf{X}_{\mathbf{2}}$ & $\mathbf{S}_{\mathbf{1}}$ & $\mathbf{S}_{\mathbf{2}}$ & $\mathbf{S}_{\mathbf{n}}$ & olusi \\
\hline $\mathrm{Z}$ & $-\mathrm{C}_{1}$ & $-\mathrm{C}_{2}$ & $0_{1}$ & $0_{2}$ & $0_{3}$ & 0 \\
\hline $\mathrm{S}_{1}$ & $\mathrm{a}_{11}$ & $\mathrm{a}_{12}$ & 1 & 0 & 0 & $\mathrm{~b}_{1}$ \\
\hline $\mathrm{S}_{2}$ & $\mathrm{a}_{21}$ & $\mathrm{a}_{22}$ & 0 & 1 & 0 & $\mathrm{~b}_{2}$ \\
\hline$\cdots$ & $\cdots$ & $\cdots$ & $\cdots$ & $\cdots$ & $\cdots$ & $\cdots$ \\
\hline $\mathrm{S}_{\mathrm{n}}$ & $\mathrm{a}_{\mathrm{m} 1}$ & $\mathrm{a}_{\mathrm{mn}}$ & $\cdots$ & $\cdots$ & 1 & $\mathrm{~b}_{\mathrm{m}}$ \\
\hline
\end{tabular}

Source: Zuhria Nasution, 2016

Information: $\mathrm{Z}=$ the objective function to be searched for the maximum or minimum value decision variable $\mathrm{Xn}$

$\mathrm{Cn}=$ Coefficient value of the objective

$\mathrm{Xn} \quad=$ nth decition variable

$\mathrm{Sn} \quad=$ nth slack variable

$\mathrm{A}(\mathrm{mn})=$ resource request for every $\mathrm{Xn} \mathrm{m}$

$$
\begin{array}{cl}
\mathrm{Bm} & =\text { number of resource provide } \\
\mathrm{n} & =\text { number of decision variables } \\
& \text { starting from } 1,2,3 \ldots \mathrm{n} \\
\mathrm{m} & =\text { number of types of resource used }
\end{array}
$$

starting from $1,2,3, \mathrm{~m}$

teh objectives of fuctions a follows:

maximize $\mathrm{Z}=\mathrm{X} 1 \mathrm{C} 1+\mathrm{X} 2 \mathrm{C} 2+\mathrm{S} 10+\mathrm{S} 2)+\mathrm{S} 30$

with limited : $\mathrm{a}_{11} \mathrm{C}_{1}+\mathrm{a}_{12} \mathrm{C}_{2}+10_{1}+00_{2}+00_{3}=\mathrm{b} 1$

$$
\mathrm{a}_{21} \mathrm{C}_{1}+\mathrm{a}_{22} \mathrm{C}_{2}+00_{1}+10_{2}+00_{3}=\mathrm{b} 2
$$

\section{ANALYSIS}

\subsection{Calculation of the Optimal Production Result Combination}

Calculation of te optimal combination production results in Roti Sahabat using linear program analysis tool, with the maximum simplex methode. From calculation above, several functions are obtained to determine the optimal production area, including

1. Purpose Fuunction

Based on the previous calculation of the contribution margin, the objecive function is

$\operatorname{Max} \mathrm{z}=321.03 \mathrm{x}+484.03 \mathrm{y}$

2. Limit Function

Raw Material $=503 x+340 y \leq 21.864 .00$

Machine Capacity $=0,2 \mathrm{x}+0,15 \mathrm{y} \leq 9.120$

Labor $=0,006 \mathrm{x}+0,0083 \mathrm{y} \leq 52.800$

Working capital $=578,97 \mathrm{x}+415,97 \mathrm{y} \leq$ 25.876 .000

To create a matrix table in calculating the combination of production results using the maximum simplex methode linear program. The following things need to be done before entering the value of the objective fuctions and limit function into the table as follows:

1. Changing the objective function, the variables that are to the rigt of the equation sign are moved to the left. So that, the form of the equation becomes:

$\mathrm{Z}=321,03 \mathrm{x}+484,03 \mathrm{y}$

$Z-321,03 x-484,03 y=0$

2. Change the shape of boundary function from the inequality $(\leq)$ into equation $(=)$ by ading slack elements of variables S1, S2, S3 and S4 so that the boundary function becomes

$503 \mathrm{x}+340 \mathrm{y}+1 \mathrm{~S} 1+0 \mathrm{~S} 2+0 \mathrm{~S} 3+0 \mathrm{~S} 4=$ 21.864 .000

$0,22 \mathrm{x}+0,13 \mathrm{y}+0 \mathrm{~S} 1+1 \mathrm{~S} 2+0 \mathrm{~S} 3+0 \mathrm{~S} 4=9.120$

$0,006 \mathrm{x}+0,0083 \mathrm{y}+0 \mathrm{~S} 1+0 \mathrm{~S} 2+1 \mathrm{~S} 3+0 \mathrm{~S} 4=$ 52.800

$578,97 \mathrm{x}+415,97 \mathrm{y}+0 \mathrm{~S} 1+0 \mathrm{~S} 2+0 \mathrm{~S} 3+1 \mathrm{~S} 4=$ 25.876 .000

where $\mathrm{x} \leq 0$ and $\mathrm{y} \leq 0$ 
After making these two changes, the into the first simplex table as follows: objective and contarint function variables can be entered

Table 4. First table Simpleks

\begin{tabular}{|c|c|c|c|c|c|c|c|}
\hline Basic & $\mathrm{X}$ & $\mathrm{Y}$ & $\mathrm{S} 1$ & $\mathrm{~S} 2$ & $\mathrm{~S} 3$ & $\mathrm{~S} 4$ & \multicolumn{1}{c|}{ RHS/Solution } \\
\hline $\mathrm{Z}$ & $-321,03$ & $-484,03$ & 0 & 0 & 0 & 0 & 0 \\
\hline $\mathrm{S} 1$ & 503 & 340 & 1 & 0 & 0 & 0 & $21.864 .000 / 340=64.305,8824$ \\
\hline S2 & 0,22 & 0,13 & 0 & 1 & 0 & 0 & $9.120 / 0,13=70.153,85$ \\
\hline S3 & 0,006 & 0,0083 & 0 & 0 & 1 & 0 & $52.800 / 0,0083=6.361 .445,78$ \\
\hline S4 & 578,97 & 415,97 & 0 & 0 & 0 & 1 & $\begin{array}{l}25.876 .000 / 415,97=62.206,4091 \\
\text { Pivot Row }\end{array}$ \\
\hline
\end{tabular}

Source : processed data, 2021

Account and fulfill the table of second simpleks with do two ways:

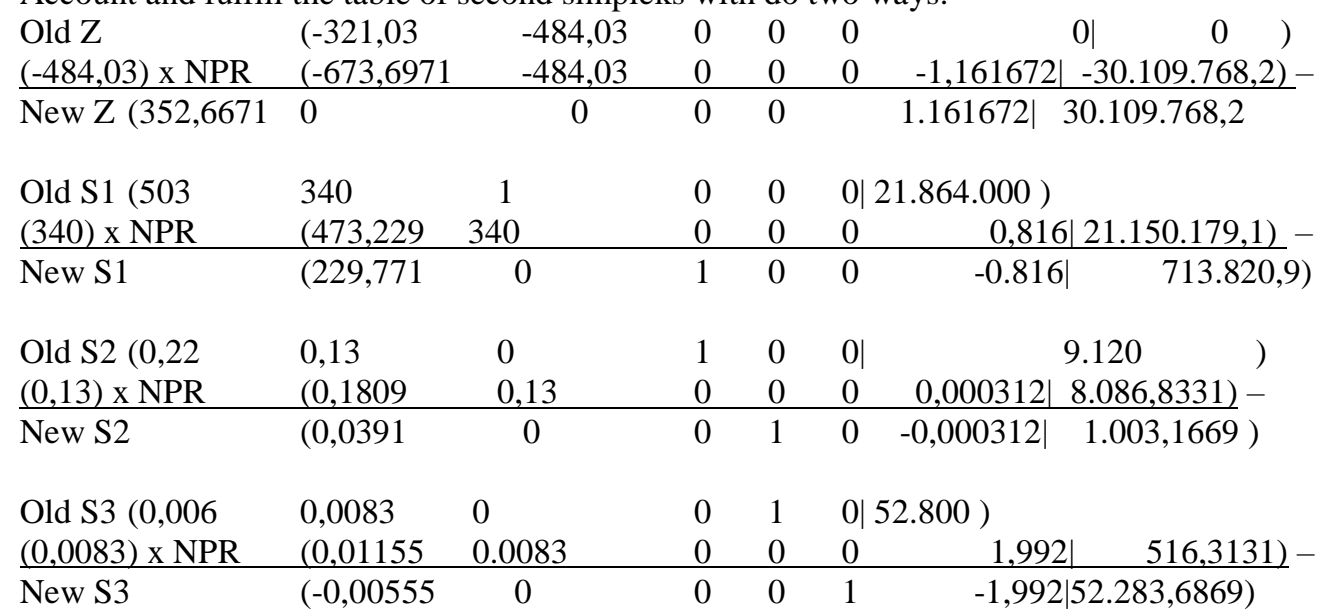

Pivot Row or S4 change by Y cause of pivot column, Y value have negative higher, so that NPR more value for Y

Table 5. Second table Simpleks

\begin{tabular}{|l|l|l|l|l|l|l|l|}
\hline Basic & $\mathrm{X}$ & $\mathrm{Y}$ & $\mathrm{S} 1$ & $\mathrm{~S} 2$ & $\mathrm{~S} 3$ & $\mathrm{~S} 4$ & RHS/Solution \\
\hline $\mathrm{Z}$ & 352,6671 & 0 & 0 & 0 & 0 & 1.161672 & $30.109 .768,2$ \\
\hline S1 & 229,771 & 0 & 1 & 0 & 0 & $-0,816$ & $713.820,9$ \\
\hline S2 & 0,0391 & 0 & 0 & 1 & 0 & $-0,000312$ & $1.003,1669$ \\
\hline S3 & -0.00555 & 0 & 0 & 0 & 1 & $-1,992$ & $52.283,6869$ \\
\hline Y & 1,39185 & 1 & 0 & 0 & 0 & 0,0024 & $62.206,4091$ \\
\hline
\end{tabular}

Source : processed data, 2021

From the results of the calculation of the linear anlysis of the maximum simplex method program in the second simplex table, it can be seen that all numbers on the $\mathrm{Z}$ line are positive [9]. This means that the second simplex table are optimal and showed the combination of production of $\mathrm{x}$ ( Pia bread) an y ( sponge bread). The RHS / solution table decribes the amount of production produced by Roti Sahabat with each amount as follow

$$
\begin{array}{ll}
\text { X (Roti Pia) } & =0 \text { unit } \\
\text { Y (Roti Bolu) } & =62.206,4091 \text { unit }
\end{array}
$$

Pia bread (x) has a value of 0,because in the second simplex table,row of $\mathrm{Z}$ there are no more negative number, so there is no need to calculated the third simplex table which to find the value of $X$. The positive $\mathrm{X}$ value is 0 
The advantage obtained by Roti Sahabat use the optimal production combination above are:

$$
\begin{aligned}
& \mathrm{Z}=321,03 \mathrm{x}+484,03 \mathrm{y} \\
& \mathrm{Z}=321,03(0)+484,03(62.206,4091) \\
& Z=0 \quad+30.109 .768,2 \\
& Z=30.109 .768,2
\end{aligned}
$$

3.2. Comparison of Product Combination and Production Profits Real with Product Combinations and production Advantages Simplex maximum Method

From the calculation results above, we can compare the number of combinationof real products with results of simplex calculation or compared real profits with the results of simplex calculation. For comparison the following table lists the real situation and simplex calculations.

Table 6. Comparison of real product and product combinationsion Simpleks Methode

\begin{tabular}{|l|l|l|l|l|l|}
\hline \multirow{2}{*}{$\begin{array}{l}\text { Product } \\
\text { Combination }\end{array}$} & \multicolumn{2}{|l|}{ Production cost } & \multicolumn{2}{l|}{ Production Volume } & \multirow{2}{*}{ Profit } \\
\cline { 2 - 5 } & Roti Pia & Roti Bolu & Roti Pia & Roti Bolu & \\
\hline Real & Rp 12.072 .000 & Rp 9.792 .000 & 24.000 & 28.800 & Rp 21.644.784 \\
\hline $\begin{array}{l}\text { Simplex } \\
\text { Method }\end{array}$ & - & Rp 21.864 .000 & - & 62.207 & Rp 30.109.768,2 \\
\hline
\end{tabular}

Source : processed data, 2021

From the data above, it can be explained that in real conditions the combination of Roti Pia and Sponge bread are 24.000 and 28.800 respectively and the monthly profit is idr.21.644.784. however the owner of Roti Sahabat used combination of product by calculated the maximum simplex method. The maximum profit obtained is idr. 30.109.768.2 in a month, where Roti Sahabat does not produce Pia bread and produces 62.206.4091 units or 62.207 units of sponge bread in a month. If used daily the maximum output of Sponge Bread after use the simplex method.

\section{CONCLUSION}

The results of this reseach and analysis based on the datas described in chapter III as follows

1. The combination of Roti Sahabat products calculated using the maximum simplex method. Linear program from Roti Sahabat only produces Sponge Bread and doesnot Pia Bread. The number of sponge bread must be produced at 62.207.4091 or 62.207 per month, or in a day Sponge bread should produce around 2.592 for maximum profit takes.

2. The maximum profit that can be achieved by Roti Sahabat (Calculated using the maximum simplex method linear program) was idr 30.109.768.2 in a month. This calculated is much higher than the monthly profit obtained by Roti Sahaba. Which was previously calculated based on manual calculations by deduction the entry of spending money. The current profit of Roti Sahabat is only idr. 21644.482 per month

\section{REFERENCES}

[1] Assauri, Sofjan. 2008. Manajemen Produksi dan Operasi Edisi Revisi. Jakarta: Lembaga Penerbit Fakultas Ekonomi Universitas Indonesia.

[2] Bungin, Burhan. 2015. Metodologi Penelitian Kuantitatif. Jakarta: Kencana Prenadaedia Group.

[3] Elisa. 2017. Manajemen Produksi dan Operasional. Palembang: Jurusan Administrasi Bisnis

[4] Herjanto, Eddy. 2010. Manajemen Operasi. Jakarta: PT Grasindo

[5] Jumarin. 2012. Optimasi Produksi Pada Perusahaan Holland Bakkery Sudirman Pekanbaru Menggunakan Linear Programming. Tugas Akhir

[6] Ngamelubun, Vinsentius dkk. 2019. Optimalisasi Keuntungan Menggunakan Metode Simpleks Pada Produksi Batu Tela. Jurnal Riset Komputer (JURNIKOM). Vol 6, N0. 5

[7]Yusi, Syahirman dan Umiyati, Idris. 2016. Metodologi Penelitian Ilmu Sosial Pendekatan Kualitatif. Palembang: Citra Books Indonesia

[8]Sayuti, abdul Jalaludin. 2013. Pengantar Bisnis. Bandung: El-falesy Publishing. 
[9]Rahayu, Yuniarsi dkk. 2014. Analisis Linear Programming Untuk Optimalisasi Kombinas Produk. Jurnal Tecno. COM. Vol. 13. No. 4

[10] Prasetya, Hery dn fitri Lukiastuti. 2015. Manajemen Operasi. Yogyakarta; Media Prassindo
[11] Sugiyono. 2018. Metode Penelitian Manajemen. Bandung: Alfabeta.

[12] Septiani, Nur. 2016. Optimasi Penentuan Kombinasi Produk Berdasarkan Perkiraan dan Metode Linear Programming (Studi Kasus UD. Bawang Putih Pati). Skripsi 